\title{
The Impact Implementation Program of Corporate Social Responsibity of PT. Kuansing Inti Makmur Toward Society Development Around Mining Area
}

\author{
Marisa Oktavia ${ }^{1,2 *}$, Maulana Yusuf ${ }^{3}$ dan Ardiyan Saptawan ${ }^{4}$ \\ ${ }^{1}$ Mining Engineering, Faculty of Technique, Sriwijaya University, Palembang \\ ${ }^{2}$ Mining Engineering, Faculty of Technique, Muara Bungo University, Jambi \\ ${ }^{3}$ Mining Engineering, Faculty of Technique, Sriwijaya University, Palembang \\ ${ }^{4}$ State Administrations, Faculty of Social and Political Sciences, Sriwijaya University, Palembang
}

\begin{abstract}
This study aims to determine the impact implementation of corporate social responsibility (CSR) program PT. Kuansing Inti Makmur (PT KIM) towards the development of communities around the tambanag area and impact of the program. The company's mission is to build sustainable growth through high standards of occupational safety, development of good community programs and robust environmental management. Corporate social responsibility has become one of the most important issues facing the mining industry. Every mining activity is required to develop and empower the communities surrounding the mining area. This is stated in Permen ESDM No 41 of 2016. Techniques in determining informants are taken by purposive sampling, the community development program consists of four areas: education, health, economics and infrastructure. Data processing research using descriptive qualitative analysis. Based on the results of research can be concluded that the impact implementation of CSR programs on community development in the education is felt by the community is enough to help with the percentage of $60 \%$, the health field is felt by the public is enough to help with the percentage of $60 \%$, the perceived the community's economy has less impact on economic improvement with $51 \%$ percentage, infrastructure perceived the community is very helpful with $80 \%$ percentage.
\end{abstract}

\section{Keywords: Implementation, Impact of CSR Implementation}

\begin{abstract}
Abstrak (Indonesian)
Tujuan dari penelitian ini untuk mengetahui dampak implementasi program corporate social responsibility (CSR) pengembangan masyarakat PT. Kuansing Inti Makmur (PT. KIM) terhadap masyarakat sekitar wilayah tambang dan dampak dari program tersebut terhadap masyarakat. Misi PT. KIM bertujuan membangun pertumbuhan berkesinambungan melalui standar keselamatan kerja yang tinggi, pengembangan program kemasyarakatan yang baik dan pengelolaan lingkungan hidup yang tangguh. Tanggung jawab sosial perusahaan telah menjadi salah satu isu yang paling penting yang dihadapi industri pertambangan. Setiap kegiatan pertambangan diwajibkan melakukan program pengembangan dan pemberdayaan terhadap masyarakat sekitar wilayah tambang yang telah diatur dalam Permen ESDM No 41 Tahun 2016. Metoda yang digunakan dalam pengambilan informan yaitu secara purposive sampling, program pengembangan masyarakat terdiri dari empat bidang yaitu bidang pendidikan, kesehatan, ekonomi dan infrastruktur. Pengolahan data penelitian menggunakan analisis deskritif kualitatif. Bedasarkan hasil penelitian dapat disimpulkan dampak implementasi program CSR pengembangan masyarakat dalam bidang pendidikan dirasakan masyarakat cukup membantu dengan persentase $60 \%$, bidang kesehatan dirasakan masyarakat cukup membantu dengan persentase $60 \%$, bidang ekonomi dirasakan masyarakat kurang berdampak terhadap peningkatan ekonomi dengan persentase $51 \%$, bidang infrastruktur dirasakan masyarakat sangat membantu dengan persentase $80 \%$.
\end{abstract}

Kata Kunci: Implementasi program pengembangan, Dampak Implementasi Program CSR

\section{Introduction}

PT. Kuansing Inti Makmur is a private company that concerns on coal mining sector which is located on Tanjung Belit village in Jujuhan Distric belongs to Bungo Regency-Jambi Province. It has vision being a well-known mining company in Indonesia by giving surplus for the customer and the stake holder. In addi-

Article History:

Received: 23 December 2017

Accepteed: 27 February 2018

DOI: $10.22135 /$ sje.2018.3.1.37-42

*Corresponding Author: marisacintamunah@gmail.com tion, it also has mission on establishing sustainability growth through a high standard of work safeness, and the development of society program and a tough cultivation of environment. According Salim, each activity of mining operation induces impact on the surrounding society, as well as the activity of the company. Its impact can be divided into two points, namely positive and negative impact[1]. The positive impact is Provide significant added value to the improvement of the national economy, increase the PAD, accommodate the mining community workforce, increase the micro-circle of mining communities, improve the quality of the mine's circular human resources and improve the health status of mining circle communities. In turn, the negative such as environmental damage, indigenous people's suffering, declining quality of life of local people and ecological damage.

The corporate social responsibility or CSR of the company has been one of the most important issues that have to be faced by the 
Table 1 General Description of Talang Silungko Village [4].

\begin{tabular}{|c|c|c|c|l|}
\hline Village & Regency & Population & $\begin{array}{c}\text { Primary of Earn } \\
\text { Living }\end{array}$ & Facilities \\
\hline Talang Silungko & Pelayang & 571 Family member/2024 people & Farming & $\begin{array}{l}\text { Education (Elementary School, Madrasah) } \\
\text { Health (Public Health Center) } \\
\text { Social (Mushola, and Mosque) }\end{array}$ \\
\hline
\end{tabular}

Table 2 General description of Tanjung Belit Village [4]

\begin{tabular}{|c|c|c|c|l|}
\hline Village & Regency & Population & $\begin{array}{c}\text { Primary of Earn } \\
\text { Living }\end{array}$ & Facilities \\
\hline Tanjung Belit & Jujuhan & 326 Family member/1168 people & Farming & $\begin{array}{l}\text { Education (Elementary School, Madrasah) } \\
\text { Social (Mublic health Center) }\end{array}$ \\
\hline
\end{tabular}

industry. Each mining activity must conduct the development and empowerment the society surrounding. It is regulated in Ministry of Human Resource and Energy No.41, 2016 about development and Society empowerment.

In order to make the mission comes true, PT KIM divides the programs into four basic programs of society development is education, health, economics, and infrastructure[2].

Based on the company mission as mentioned about, the writer is interested in knowing deeply about the impact implementation of CRS from PT. KIM toward the society development. Based on the background above, it can be concluded the formulation of the problem as follow;

1. How is the implementation of CRS Program From PT.KIM To ward the society

2. How much the impact after the implementation of CSR Program toward society who accepted help?

\section{Research Method}

\subsection{Research Approach}

The approach that is used in the research is descriptive qualitative method, in order to describe and explain the implementation of CSR Program from PT.KIM toward society in mining area

\subsection{Kind and Source of Data}

The primary data is the data that is obtained from the informant by applying some ways/technique, namely asking question and answer which guided by questions that related to research focus prepared before. The secondary data is data that is obtained from some sources of information, as below;

1. Annual report from PT.KIM

2. Scientific Books and some related references

\subsection{Technique of Collecting Data}

Technique of collecting Data that is used in the research divided into two ways, namely library research and field research. Library research dealt with looking and collecting some related materials to the research such as, books of manual technique and some theories related that can be used in the research. Meanwhile, field research is going to the field directly to obtain data by observing, interviewing, and documenting.

\subsection{Technique of Informant Criteria}

Technique of Informant Criteria was taken by purposive sampling, which means that the informant is chosen based on the research field dealing with the formulation of the problem.

\subsection{Technique of Data Cultivation}

Technique of Data Cultivation used descriptive qualitative technique based, by collecting, reducing, presenting, and concluding [3].

\subsection{Technique of Data Analysis}

Data that has been collected and cultivate should be analyzed in order to know the implementation of CSR Program From PT.KIM toward the society by using analysis technique of triangulation of data source by comparing the early plan of CSR toward the implementation and some factors that influence the program and the impact toward society, especially the receiver.

\section{Result And Discussion}

\subsection{General Description Of Two Founding Village}

PT.KIM has two founding, namely, Bathin II Pelayang and Jujuhan. Bathin II Pelayang has four districs, Pelayang, Kerakap, Seberang Jaya, and Talang Silungko. Bathin II Pelayang gets the direct impact and close to the mining operation, Dusun Talang Silungko and belongs to Area I. Another one is not directly influenced by the operation. Jujuhan has four sub-districts that gets directly 
Table 3. Education development Program Plan Year 2013-2016 [5]

\begin{tabular}{|c|c|c|c|}
\hline 2013 & 2014 & 2015 & 2016 \\
\hline $\begin{array}{l}\text { 1. SD Achievement } \\
\text { scholarships } \\
\text { 2. Schools targeted }\end{array}$ & $\begin{array}{l}\text { 1. SD Achievement scholarships } \\
\text { 2. Schools targeted }\end{array}$ & $\begin{array}{l}\text { 1.Try Out And Bimbel Junior And Senior } \\
\text { High School } \\
\text { 2. MA Delegate Scholarship }\end{array}$ & $\begin{array}{l}\text { 1. Try Out And Bimbel } \\
\text { Junior And Senior High } \\
\text { School } \\
\text { 2. SD Achievement Schol- }\end{array}$ \\
\hline $\begin{array}{l}\text { 3. The program compul- } \\
\text { sory education aksara } \\
\text { alquran }\end{array}$ & 3. Scouts, Youth And Sports & 3. SD Achievement Scholarship & 3. Scouts, Youth And Sports \\
\hline \multirow[t]{4}{*}{$\begin{array}{l}\text { 4. Scouts, Youth And } \\
\text { Sports }\end{array}$} & & 4. Scouts, Youth And Sports & 4. Schools Targeted \\
\hline & & 5. Schools Targeted & $\begin{array}{l}\text { 5. Muara Bungo University } \\
\text { Cooperation }\end{array}$ \\
\hline & & 6. Muara Bungo University Cooperation & 6. Training \\
\hline & & 7. Training & \\
\hline
\end{tabular}

Table 4. Healt development Program Plan Year 2013-2016 [5]

\begin{tabular}{|l|l|l|l|}
\hline \multicolumn{1}{|c|}{$\mathbf{2 0 1 3}$} & \multicolumn{1}{|c|}{$\mathbf{2 0 1 4}$} & \multicolumn{1}{|c|}{$\mathbf{2 0 1 5}$} & \multicolumn{1}{|c|}{$\mathbf{2 0 1 6}$} \\
\hline 1. Posyandu & 1. Posyandu & 1. Posyandu & 1. Posyandu \\
2. Free dental examination for elementary school children & 2. Mass circumcision & 2. Mass circumcision & 2. Mass circumcision \\
3. PHBS in School & 3. PHBS in School & 3. PHBS in School & 3. PHBS in School \\
\hline
\end{tabular}

impact from the operation and belong to Area II, Tanjung Belit.

\subsubsection{General Description of Talang Silungko Village}

General description Dusun Talang Silungko Can be seen in table 1 below.

\subsubsection{General Description of Tanjung Belit Village}

General description Dusun Tanjung Belit Can be seen in table 1 below.

\subsection{General Description of PT.KIM}

PT.KIM is a private company that concerns on coal mining sector. It is one of branches of PT.Golden Energy Mines Tbk that concers on trading of mining products and mining services. It is located in Tanjung Belit Village Jujuhan Bungo Jambi Province.

The mining system that used by PT.KIM is open pit mining with back filling digging method. Its legal area around 2610 Hectare with $4700 \mathrm{Kcal} / \mathrm{Kg}$ for calori. In its mining activity, PT.KIM is helped by one subcontractor, that is PT. Artamulia Tata Pratama by production target around 4.250.000 ton/Year.

\subsection{The background of CSR PT.KIM}

Based on government law/UU, CSR is one commitment from the business company in giving contribution toward the sustainability of economics development, and increase the living quality and environment can be useful for internal citizen, external, community as well as society.

The commitment of PT.KIM responsibility on social and environment can be seen from its mission, namely established the sustainability growth through the high standard of safety on work, the development of society program and cultivation of the living. The purpose of CRS externally is giving the contribution in improving the human development index through empowerment program.

In contrast, the purpose of CRS internally is the establishing a harmonic relationship with the stake holder that contributed in goal oriented of reputation. It matches with the company's vision that being well-known mining company in Indonesia by creating the surplus for the customer and the stakeholder.

\subsection{Development Program Plan}

The community development program plan consists of four areas: education, health, economy and infrastructure. The CSR program of education, health, economy and infrastructure development from 2013-2016 can be seen in table 3,4,5,6 as follow; 
Table 5. Economi development Program Plan Year 2013-2016 [5]

\begin{tabular}{|c|c|c|c|}
\hline 2013 & 2014 & 2015 & 2016 \\
\hline 1. House of Food 'Lestari' & 1. Turmeric cultivation, ginger & 1. Unite Agriculture & 1. Unite Agriculture \\
\hline 2. Unite Agriculture & 2. Cow cultivation & 2. Fishery Cultivation & 2. Fishery \\
\hline 3. Community Learning Center & 3. Husbandry & 3. Husbandry & 3. Husbandry \\
\hline \multirow[t]{4}{*}{ 4. Social meaning economics } & 4. Cultivation & 4. Agriculture & 4. Agriculture \\
\hline & 5. Cow Cultivation & & 5. Food Cultivation \\
\hline & 6. Training & & 6. Cow greasing \\
\hline & 7. Lele Cultivation & & \\
\hline
\end{tabular}

Table 6. Infrastructure development Program Plan Year 2013-2016 [5]

\begin{tabular}{|c|c|c|c|}
\hline 2013 & 2014 & 2015 & 2016 \\
\hline 1. School infrastructure facilities & $\begin{array}{l}\text { 1. Development of elementary } \\
\text { school fence Tanjung Belit }\end{array}$ & 1. School facilities & 1. School Facilities \\
\hline 2. General infrastructure facilities & $\begin{array}{l}\text { 2. School / Madrasah Infrastruc- } \\
\text { ture } \\
\text { 3. Improvement of Talang Silung- } \\
\text { ko Mosque } \\
\text { 4. Improvement of the Balai Pan- } \\
\text { jang Mosque } \\
\text { 5. Repairing the ring road Talang } \\
\text { Silungko } \\
\text { 6. improvement of Jelemu Island } \\
\text { Hamlet road } \\
\text { 7. MCK Kampung Jawa }\end{array}$ & $\begin{array}{l}\text { 2. General infrastructure facilities } \\
\text { 3. Health facilities } \\
\text { 4. Means of CSR activities }\end{array}$ & $\begin{array}{l}\text { 2. Public Infrastructure } \\
\text { Facility } \\
\text { 3. Health Facilities }\end{array}$ \\
\hline
\end{tabular}

\subsection{The Implementation program of CSR}

ISO 26000 stated that CSR is the responsibility of a company on the impact from its decision and activity toward society from the environment through opened attitude and ethic, consistence with the sustainable development and society wealth, concern on the expectation of the stake holder, obey to the law and consistence with the international norms and can be integrated into organizational part.

CSR is an ongoing commitment of ethically running companies and has contributed to economic development to improve the quality of life of the workforce and their families and communities as well as the wider community[6]. The company engages in CSR activities to gain legitimacy from the community. The legitimacy of the organization can be seen as something that society gives to the company and something the company wants or sought from society [7].

Based on direct interviews with various informants consisting of Hamlet Device and Dusun community who received CSR aid and who did not receive CSR assistance. Implementation of CSR program plan PT. KIM in various fields can be explained as follows:

The implementation of community development program consists of four areas, namely education, health, infrastructure and economy. In the field of education from 2013 to 2016, implementation of CSR program plans such as achievement scholarships and grant funds, target schools, school facilities and infrastructure have been running well and the percentage of achievement by $90 \%$. In the health sector from 2013 to 2016, the implementation of CSR program plans such as posyandu activities of supplementary feeding and free milk, mass circumcision, clean and healthy life behavior in school (PHBS), and free dental examination. Implementation of the program has been running well enough and the percentage of achievement of 58\%. Infrastructure programs from 2013 to 2016 program implementation such as the development of water sources for hamlets, school facilities and infrastructure, mosque and mosque repair, road improvements, health facilities and so on have run very well and $100 \%$ achievement percentage. Implementation of CSR program plan in the economic field from 2013 to 2016 such as cultivation of agriculture, livestock, fishery, processed food and integrated agricultural training center, implementation is not run- 
ning well and the percentage of achievement of $33 \%$.

The goal of community development is to generate full citizen participation with the ultimate goal of realizing the ability and integration of communities to build themselves[8]. Based on the results of interviews with informants, the implementation of community development programs in the economic field has not been achieved or implemented properly. The development program plan is based on the results of social mapping, but in the implementation of the program plan is not running properly or not on target. This is caused by the implementation system of the company and the community. in terms of company pihaka due to lack of socialization, coaching and firmness of the company to the hamlet and the community who receive assistance. On the part of the community due to the lack of participation and commitment of the community to implement the program and the program is not in accordance with the main eye of society.

The results of this study is different from previous research conducted by Antonius, that in order to plan the program of CSR activities can be run in accordance with the goals and plans and the right target should be proposed by the community[9]. It also supported by Ryan, that lack of escorting the society can also cause the failure of the program[10].

\subsection{The Impact of Program Implementation toward the society who receive the donation}

Based on the results of direct interviews with beneficiary informants, both the constructed area of ring 1 and the target area of ring 2 obtained the results of triangulation analysis of data sources, the impact of CSR program implementation PT. KIM to the development of the communities surrounding the mine area and the recipient community of CSR assistance in the following areas.

\section{a. Education}

The impact of the implementation of the CSR program provided by the company in the field of education to the communities surrounding the mine area is enough to help the community with a percentage of $6.0 \%$. Public perceptions of CSR program implementation as follows:

"The positive impact of the mining activities is according to Rio Dusun Tanjung Belit" since the existence of PT. KIM has a positive impact in the field of education such as awarding national exam achievement scholarships and guidance for junior and senior high school students. "According to the mother of the children receiving scholarship achievement of national exam and class rankings" the program is very helpful and improve the competitiveness of children in achievement ".

\section{b. Health}

The impact of CSR implementation of PT. KIM in the field of health such as posyandu is quite helpful and promotes posyandu with a percentage of $55 \%$. Public perceptions of the impact of the program are as follows:

In the health field according to midwife Dusun "since the assistance of additional feeding and free milk from KIM for mother and toddler to posyandu, malnutrition rate in underfive and pregnant mother become reduced because society become diligent to come routine to health center every month health check. According to the malnourished under-five mother of the beneficiaries of free milk and money, the aid is very helpful for improving her child's health.

\section{c. Economy}

The impact of the community economic development program has not hit the target or has not affected the CSR recipient community as stated by the residents who receive the assistance of "CSR program of pond water fish farms in and goat, this program does not increase the income because food price is more expensive than the selling price of fish and maintenance of the goats that must be cherished.

The same thing is also conveyed by the community receiving duck aquaculture as well as Rio Balai Panjang, that the cost of animal feed is more expensive than the income generated from the egg of the duck.

For the cultivation of vegetables according to residents who receive assistance "vegetable cultivation program on the home page can reduce the cost of daily kitchen expenditure of one hundred thousand rupiah per month.

Residents who received the help of oyster mushroom cultivation said that the program does not have an impact on economic growth because the treatment of the fungus is difficult and not in accordance with regional climatic conditions ".

\section{d. Infrastructure field}

Impact of CSR program implementation PT. KIM in the field of development or infrastructure such as the construction of bridges, waterways and so forth is very helpful community around the mining area with a percentage of $80 \%$. Public perceptions of the impact of program implementation are as follows:

According to residents of Dusun Tanjung Belit, the construction of concrete bridge is very helpful to the residents so that people who used to cross by using suspension bridges that can only be passed by two-wheeled vehicles, now four-wheeled vehicles can cross them.

The same thing is also conveyed by Rio Dusun Rantau ikil "since the existence of PT. KIM Dusun becomes more advanced and many changes, which previously people do not have a drinking water supply now has a pure drinking water supply by the company ".

According to Rio Dusun Balai Panjang, Rio Talang Silungko and Dusun community "since the existence of mining activities of PT. KIM provides a very perceived impact of the community in the field of hamlet road construction so as to facilitate access to marketing of community gardens and communities that used to out of the hamlet must menemph time for days now only takes 20 minutes ".

Based on the interview with the receiver of donation of CRS program haven't got the right person yet. It was reported by the receiver of cow husbandry and fish. . This is because in the implementation of the program is influenced by the implementation of the system is the lack of socialization and coaching from the company to the community receiving CSR assistance and the absence of monitoring and evaluation of the company against the impact of the program to the beneficiary community. The achievement of the program towards economic improvement is also influenced by community participation and commitment in running the program. For the field of education, health, community relations, development is very useful and can be felt directly by the community.

It is based on Andi's research, if CSR can fulfill what people need, it will give the influence on the level of society wealth[11]. The research is supported by previous study by Lestari, that the 
obstacle influenced the CSR derived from the system (of human resources) who run the system[12]

\section{Conclusion}

Implementation of community development CSR program PT. KIM to communities around the mining area is divided into four areas namely the field of education, health, economy and infrastructure. The achievement of the CSR program is very good with the percentage of $95 \%$, the public health sector is quite good with the percentage of $58 \%$, the economic field is not good with the percentage of $33 \%$ and the implementation of CSR infrastructure is very good and reached $100 \%$.

Factors that affect the unfulfillment of CSR development program implementation of PT. KIM is influenced by the implementation system that is in terms of company lack of socialization, coaching and unfavorable developmen strategy resulted in the program plan is not running well / slow. Another factor affecting the non-achievement of the program is the participation of the community itself which is a major component in the achievement of the program.

Impact of CSR community development program implementation PT. KIM to communities around the mining area as follows in the field of education impact on the community enough to help with the percentage of $6.0 \%$, implementation in the field of health such as posyandu enough help and promote posyandu with percentage of $57 \%$, the implementation of CSR programs in economics such as agricultural cultivation, livestock and fishery have less impact to economic improvement of beneficiary community with percentage $51 \%$ and implementation of CSR program in infrastructure such as bridge construction, clean water road and so forth very help society around mining area with percentage $80 \%$.

\section{References}

Hakim Ilmi, 2014. "Impact of Mining Policy for Bengkuring Community of Sempaja Selatan Sub- District of North Samarinda District”. ejournal Governmental Science, Volume 2 No. 1 Year 2014. Annual Report 2016.

Sugiyono, 2009. "Qualitative Quantitative Research Methods and RD”. Alfabeta Publisher. Bandung.

Social Mapping PT. KIM Year 2013.

Coroprate Social Responsibility Report 2013-2016.

Ardianto Elvinaro and Machfudz. 2012. "Effect of Generosity of Businessman and Corporate Social Responsibility". Jakarta. Elek Media Komputindo.

O'donovan, Garry. 2002. "Enviromental Disclourse In The Annual Report: Extending The Applicability and Predictive Power of Legitimacy Theory". Journal of Accounting, Auditing and Accountability, Vol 15 No. 3 Year 2002.

Budi Wibhawa and Santoso, 2010. "The foundations of social workers". Widya Padjajaran. Bandung

Suhadi Antonius and Turatmiyah. S, 2014. "CSR Model of Coal Mining Company in Lahat District On Community Based Wisdom Local Empowerment". Journal of Law Dynamics, Vol 14 No. 1 Year 2014

Randika Ryan. 2015. "Impact of CSR Program PT. Kaltim Prima Coal in Sepaso Village, Bengalon Subdistrict, East Kutai Regency". Journal of Government Science, Volume 3 No. 1 Year 2015

Mapisangka Andi. 2009. Implementation of CSR on Community Welfare, Journal of Public Administration, Volume 1 No. 5 Year 2009.

Lestary Ayu, 2014. "CSR PT. Surya Teknik Anugrah Atas Usaha Mining Coal In Loa Duri Ilir Subdistrict Loa Janan Subdistrict Kutai Kartanegara Regency”. ejurnal State Administration, Volume 3 No 2 Year 2014. 